\title{
IN VITRO ANTIDIABETIC ACTIVITIES OF EXTRACT AND ISOLATED FLAVONOID COMPOUNDS FROM Artocarpus altilis (Parkinson) FOSBERG
}

\author{
Puspa Dewi Narrij Lotulung, Tjandrawati Mozef*, Chandra Risdian, and Akhmad Darmawan \\ Research Center for Chemistry, Indonesian Institute of Sciences \\ Kampus LIPI Gd. 50, Jl. Sangkuriang Bandung, Indonesia
}

Received November 4, 2013; Accepted December 13, 2013

\begin{abstract}
The antidiabetic activity test through a mechanism of inhibition of $\alpha$-glucosidase enzyme was studied against ethanol, $n$-hexane, ethyl acetate and $n$-butanol fractions of ethanol extract of Artocarpus altilis (Parkinson) Fosberg (Moraceae) leaves and four flavonoid compounds isolated from ethyl acetate extracts of $\underline{A}$. altilis. Ethyl acetate fraction has strongest antidiabetic activity compared to ethanol, $n$-hexane, and $n$-butanol fractions with $I C_{50}$ values 5.98, 6.79, 440.18 and $14.42 \mu \mathrm{g} / \mathrm{mL}$, respectively. Four flavonoid compounds (1-(2,4-dihydroxyphenyl)-3-[8-hydroxy2-methyl-2-(4-methyl-3-pentenyl)-2H-1-benzopyran-5-yl]-1-propanone (AC-31), 2-geranyl-2',3,4,4'-tetrahydroxy dihydrochalcone (AC-51), 8-geranyl-4',5,7-trihydroxyflavone (AC-33) and cyclocommunol (AA-3), have been isolated from ethyl acetate fraction. AC-31 was the strongest antidiabetic compound compared to AC-51, AC-33 and cyclocommunol with $I C_{50}$ values are $15.73,24.41,49.49$, and $72.20 \mu \mathrm{g} / \mathrm{mL}$. Kinetic studies of $A C-31$ using Lineweaver-Burk method showed that inhibition mechanism of enzyme $\alpha$-glucosidase was a non-competitive type.
\end{abstract}

Keywords: Artocarpus altilis; antidiabetic; $\alpha$-glucosidase; flavonoid

\section{ABSTRAK}

Uji aktivitas antidiabetes melalui mekanisme penghambatan aktivitas enzim a-glukosidase telah dilakukan terhadap fraksi etanol, $n$-heksana, etil asetat, dan butanol dari ekstrak etanol daun Artocarpus altilis (Parkinson) Fosberg (Moraceae) dan empat senyawa flavonoid hasil isolasi dari ekstrak etil asetat tanaman yang sama. Fraksi etil asetat mempunyai aktivitas antidiabetes paling kuat dibanding dengan fraksi etanol, $n$-heksana dan butanol dengan nilai $I C_{50}$ berturut-turut $5,98,6,79,440,18$ dan $14,42 \mu \mathrm{g} / \mathrm{mL}$. Empat senyawa flavonoid $(1-(2,4-$ dihidroksifenil)-3-[8-hidroksi-2-metil-2-(4-metill-3-pentenil)-2H-1-benzopiran-5-yl]-1-propanon (AC-31), 2-geranil2',3,4,4'-tetrahidroksidihidrochalkon (AC-51), 8-geranil-4',5,7-trihidroksiflavon (AC-33) dan siklokomunol (AA-3) merupakan senyawa-senyawa hasil isolasi dari fraksi etil asetat. AC-31 merupakan senyawa dengan aktivitas antidiabetes paling kuat dibanding dengan $A C-51, A C-33$, dan siklokomunol dengan nilai $I C_{50}$ berturut-turut 15,73; 24,41; 49,49 and $72,20 \mu \mathrm{g} / \mathrm{mL}$. Studi kinetik yang dilakukan menggunakan metoda Lineweaver-Burk menunjukkan bahwa mekanisme penghambatan aktivitas enzim a-glukosidase oleh senyawa AC-31 mempunyai tipe nonkompetitif.

Kata Kunci: Artocarpus altilis; antidiabetes; $\alpha$-glukosidase; flavonoid

\section{INTRODUCTION}

Diabetes mellitus (DM) is a chronic disease caused by inherited and/or acquired deficiency in production of insulin by the pancreas, or by the ineffectiveness of the insulin produced [1]. DM can be classified into 2 types: DM type 1 (insulin-dependent diabetes mellitus or IDDM) and DM type 2 diabetes (non-insulin dependent diabetes mellitus or NIDDM). In DM type 2, insulin-resistance is a characteristic feature and several drugs to increase the insulin sensitivity are currently being used in clinic [2]. At the present time, it is estimated that 150 million people worldwide have diabetes and that this will increase to 220 million by 2010 and 300 million by 2025 [3].

* Corresponding author. Tel/Fax : +62-22-250305

Email address : tjandrawm@yahoo.com
Indonesian health research foundation in 2007 showed that DM is a serious health problem for Indonesian peoples with $14.7 \%$ proportion of deaths due to diabetes disease in the age 45-54 years.

DM is a debilitating and often life-threatening disorder with increasing incidence throughout the world [2]. Diabetic complications arise partly from glycosylation damage to structural and functional proteins and reflect chronic failure to maintain blood glucose homeostasis. Other complications such as diabetic nephropathy, diabetic retinopathy, diabetic neuropathy and diabetic cardiomyopathy prevail as a result of hyperglycemia. The pathophysiology involves an interaction between metabolic and hemodynamic 
factors. Metabolic factors include advanced glycation, increased formation of polyols and activation of protein kinase-C. Hemodynamic factors include systemic hypertension, intraglomerular hypertension and the role of vasoactive hormones, such as anglotensin II. Clinical course progresses from microalbuminuria to overt proteinuria and then to renal failure [5].

Dietary intake is related to blood glucose levels, and it is considered to be important to suppress hyperglycemia induced by overeating in order to prevent worsening of the symptoms in the hyperglycemic individuals with uncertain diabetic status. Inhibition of $\alpha$ glucosidase is one way that could do in order to suppressing postprandial hyperglycemia. By inhibition the activity of enzyme will affect to the delaying glucose absorption, controlling the hyperglycemia [6-7] and reducing chronic vascular complications [8]. Therefore, by using $\alpha$-glucosidase inhibitors is a cost-effective means to preventing the progression of diabetes [9-10].

Several inhibitors of this enzyme have been reported such as acarbose, voglibose, miglitol [11], nojirimycin and 1-deoxynojirimycin from plants [12]. Plants as sources of medicinal compounds have long been used by people. With a wealth of biodiversity, Indonesia has potential resources of various plants with various active compounds content which could inhibit the activity of enzyme a-glucosidase to overcome the disease diabetes [3-4]. Artocarpus altilis (Parkinson) Fosberg is a tropical plant, widely distributed in the tropics regions including Indonesia. Various parts of the plant, from leaves, latex, bark, roots were used as traditional medicine for various diseases ranging from infectious diseases (skin, urinary tract, and ear), diarrhea, dysentery, oral inflammation, fever, liver to diabetes and hypertension [13]. In vivo experiments showed that ethanol extract of $A$. altilis leaves (10 and $20 \mathrm{mg} / \mathrm{kg}$ ) can reduced blood glucose levels significantly [16]. In this study, we investigated the inhibitory effect of $A$. altilis leaves extracts and four isolated flavonoid compounds on a-glucosidase activity. We also investigated kinetics inhibition reaction of the compounds.

\section{EXPERIMENTAL SECTION}

\section{Materials}

Artocarpus altilis leaves was collected from Parung, Bogor, Indonesia in March 2006 and determined at Herbarium Bogoriense, Research Center for Biology, Indonesian Institute of Sciences.

Four flavonoid compounds isolated from $A$. altilis (collection of Research Center for Chemistry, Indonesian Institute of Sciences) AC-31 (1-(2,4-dihydroxyphenyl)-3[8-hydroxy-2-methyl-2-(4-methyl-3-pentenyl)-2H-1- benzopyran-5-yl]-1-propanone), AC-51 (2-geranyl2',3,4,4'-tetrahydroxydihydrochalcone), AC-33 (8-gera nyl-4, 5,7-trihydroxyflavone) and cyclocommunol (AA-3) [13-14].

Ethanol, $n$-hexane, ethyl acetate, $n$-butanol, enzyme $\alpha$-glucosidase, $\quad p$-nitrofenil- $\alpha$-D-glukopirano sida ( $p-N P G)$, bovine serum albumin and quercetin from Sigma. Solution of sodium bicarbonate and Dimethylsulfoxide (DMSO) from Merck.

\section{Instrumentation}

In this study, we used various instruments to support our research such as: macerator, rotary evaporator, and ELISA reader.

\section{Procedure}

\section{Extraction}

Powdered and dried of $A$. altilis leaves $(4.95 \mathrm{Kg})$ were extracted exhaustively with ethanol $70 \%$. The ethanol extracts $(250 \mathrm{~g})$ were concentrated using vacuum rotary evaporator and then partitioned with $n$-hexane, ethyl acetate and $n$-butanol.

a-Glucosidase activity. Xa-glucosidase enzyme activity was analyzed using Sancheti method (Sancheti et al., 2009) with modifications. $0.001 \%$ enzyme stock solution dissolved in phosphate buffer solution $(\mathrm{pH} 7)$ contained $0.2 \%$ bovine serum albumin. Enzymatic reactions by mixing $25 \mu \mathrm{L} 20 \mathrm{mM}$ p-NPG as the substrate, $45 \mu \mathrm{L}$ phosphate buffer solution and $5 \mu \mathrm{L}$ samples were then added to the homogeneous a-glucosidase enzyme was diluted 50 times in phosphate buffer solution. The reaction mixture then water-bath incubated at $37^{\circ} \mathrm{C}$ for $30 \mathrm{~min}$. The reaction was stopped by the addition of $100 \mu \mathrm{L} 0.2 \mathrm{M}$ of $\mathrm{Na}_{2} \mathrm{CO}_{3}$ solution. The resulted $p$-nitrophenol was measured at $\lambda 400 \mathrm{~nm}$ using ELISA reader. The experiments were performed with 3 replicates and \% inhibition was calculated using the following formula:

$\%$ Inhibition $=\frac{\mathrm{C}-\mathrm{S}}{\mathrm{C}} \times 100 \%$
$\mathrm{C}$ absorbance without sample
$\mathrm{S}$ absorbance with the sample

\section{Kinetics inhibition against $\alpha$-glucosidase enzyme}

Kinetics inhibition against $\alpha$-glucosidase enzyme was analyzed by measuring the formation of $p$-NP on the time interval 0 to $20 \mathrm{~min}$ with a variety of $p-\mathrm{NPG}$ substrate concentrations between 1 to $20 \mathrm{mM}$ with or without samples. Linewaver-Burk method used to determine the type of inhibition to create a graph plot $1 / \mathrm{v}$ (speed of reaction) against 1/[S] (substrate concentration changes are directly proportional to the product formation). 

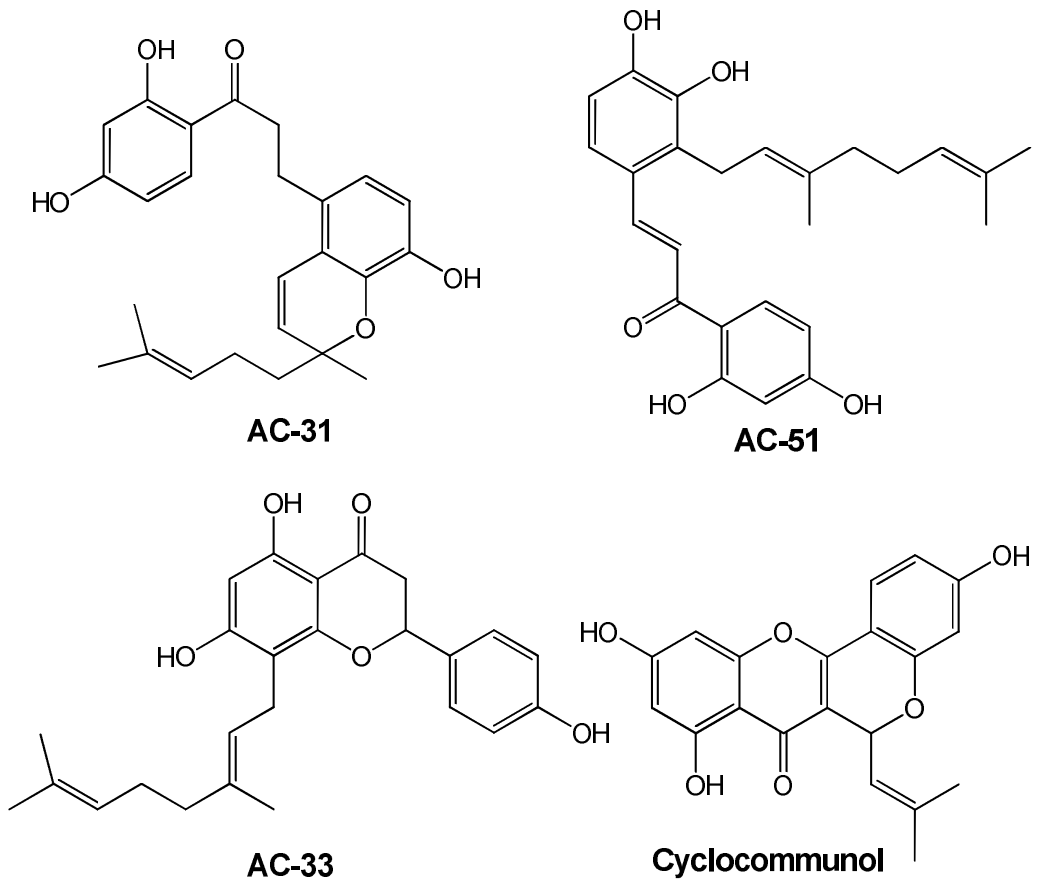

Fig 1. Chemical structure of flavonoid compounds isolated from A. Altilis

Table 1. Enzyme a-glucosidase inhibition activity of A. altilis leaves ethanol extract and its fractions.

\begin{tabular}{ll}
\hline & $\mathrm{IC}_{50}(\mu \mathrm{g} / \mathrm{mL})$ \\
\hline Quercetin & 11.60 \\
Ethanol & 6.79 \\
$n$-Hexane & 440.18 \\
Ethylacetate & 5.98 \\
$n$-Butanol & 14.42 \\
\hline
\end{tabular}

\section{RESULT AND DISCUSSION}

a-Glucosidase inhibition activities of each sample was compared by $\mathrm{IC}_{50}$ value resulted in the experimental condition. Smaller $\mathrm{IC}_{50}$ values mean stronger inhibition activity. Ethanol extract showed stronger inhibition activity against $\alpha$-glucosidase compared with quercetin as positive control with $\mathrm{IC}_{50} 6.79 \mu \mathrm{g} / \mathrm{mL}$. Further fractionation of the ethanol extract showed that the ethyl acetate fraction was the strongest fraction with $\mathrm{IC}_{50} 5.98$ $\mu \mathrm{g} / \mathrm{mL}$ (Table 1). This result suggests that the active compounds from the ethanol extract concentrated on semi polar fraction, and flavonoids were the active major compounds contained in $A$. altilis plant.

AC-31 (1-(2,4-dihydroxyphenyl)-3-[8-hydroxy-2methyl-2-(4-methyl-3-pentenyl)-2H-1-benzopyran-5-yl]-1propanone), yellow crystal, $\mathrm{H}-\mathrm{NMR}$ (in $\mathrm{CDCl}_{3}, \mathrm{ppm}$ ) $\delta_{H} 6.38(1 \mathrm{H}, \mathrm{d}, J=2.45 \mathrm{~Hz}, . \mathrm{H}-2) ; 6.37(1 \mathrm{H}, \mathrm{dd}, J=2.45$; $8.5 \mathrm{~Hz}, \mathrm{H}-4), 7.54(1 \mathrm{H}, \mathrm{d}, J=8.5 \mathrm{~Hz}, \mathrm{H}-5) ; 3.1(2 \mathrm{H}, \mathrm{q}, \mathrm{H}-$ 8); $2.9(2 \mathrm{H}, \mathrm{M}, \mathrm{H}-9) ; 6.60(1 \mathrm{H}, \mathrm{d}, J=8.5 \mathrm{~Hz}, \mathrm{H}-11) ; 6.72$ $(1 \mathrm{H}, \mathrm{d}, J=8.5 \mathrm{~Hz}, \mathrm{H}-12) ; 6.54(1 \mathrm{H}, \mathrm{d}, 9.8 \mathrm{~Hz}, \mathrm{H}-16) ; 5.63$ $(1 \mathrm{H}, \mathrm{d}, 9.8 \mathrm{~Hz}, \mathrm{H}-17) ; 1.70(2 \mathrm{H}, \mathrm{m}, \mathrm{H}-19) ; 2.09(2 \mathrm{H}, \mathrm{m}$,
$\mathrm{H}-20) ; 5.08$ (1h, t, H-21); 1.66 (3H, s, H-23); 1.57 (3H, $\mathrm{s}, \mathrm{H}-24) ; 1.28$ (3H, s, H-25); ${ }^{13} \mathrm{C}-\mathrm{NMR}$ (in $\mathrm{CDCl}_{3}, \mathrm{ppm}$ ) $\delta_{\mathrm{C}} 165.2(\mathrm{C}-1), 103.6$ (C-2), 163.48 (C-3), 108.3 (C-4), 132.45 (C-5), 113.6 (C-6), 204.1 (C-7), 39.8 (C-8), 26.7 (C-9), 128.8 (C-10), 121.29 (C-11), 114.7 (C-12), 143.1 (C-13), 139.7 (C-14), 119.2 (C-15), 119.5 (C-16), 130.3 (C-17), 78.9 (C-18), 40.9 (C-19), 22.9 (C-20), 123.9 (C-21), 132.1 (C-22), 25.8 (C-23), 17.8 (C-24), 26.2 (C-25). Molecular weight with [M+] 409.5460 [17].

AC-51 (2-geranyl-2', 3,4,4'-tetrahydroxydihydro chalcone), yellow gum, ${ }^{1} \mathrm{H}-\mathrm{NMR}$ (in $\mathrm{CDCl}_{3}, \mathrm{ppm}$ ) $\delta_{\mathrm{H}} 6.71(1 \mathrm{H}, \mathrm{d}, 8.2 \mathrm{~Hz}, \mathrm{H}-5) ; 6.65(1 \mathrm{H}, \mathrm{d}, J=8.2 \mathrm{~Hz}$, $\mathrm{H}-6) ; 3.11(2 \mathrm{H}, \mathrm{t}, \quad J=7.8 \mathrm{~Hz}, \mathrm{H}-\alpha) ; 2.97(2 \mathrm{H}, \mathrm{t}$, $J=7.8 \mathrm{~Hz}, \mathrm{H}-\beta), 6.37\left(1 \mathrm{H}, \mathrm{d}, J=2.4 \mathrm{~Hz}, \mathrm{H}-3^{\prime}\right) ; 6.35(1 \mathrm{H}$, $\left.\mathrm{dd}, J=8.7,2.4 \mathrm{~Hz}, \mathrm{H}-5^{\prime}\right) ; 7.58\left(1 \mathrm{H}, \mathrm{d}, J=8.7 \mathrm{~Hz}, \mathrm{H}-6^{\prime}\right)$; 3.40, $(2 \mathrm{H}, \mathrm{d}, J=6.7 \mathrm{~Hz}, \mathrm{H}-1$ "); $5.17(1 \mathrm{H}$, brt, $J=6.7 \mathrm{~Hz}$, $\mathrm{H}-2 ") ; 2.06(2 \mathrm{H}, \mathrm{t}, J=6.2 \mathrm{~Hz}, \mathrm{H}-4 ") ; 2.08(2 \mathrm{H}, \mathrm{q}$, $J=6.2 \mathrm{~Hz}, \mathrm{H}-5$ "); $5.02(1 \mathrm{H}, \mathrm{brt}, J=6.2 \mathrm{~Hz}, \mathrm{H}-6 ") ; 1.79$ (brs, 3H, H-8"); 1.57 (brs, 3H, H-9"); 1.66 (brs, 3H, $\mathrm{H}-10$ ). ${ }^{13} \mathrm{C}-\mathrm{NMR}$ (in $\mathrm{CDCl}_{3}, \mathrm{ppm}$ ) $\delta_{\mathrm{C}} 131.1$ (C-1), 126.1 (C-2), 142.4 (C-3), 142.6 (C-4), 112.9 (C-5), 121.3 (C-6), 113.5 (C-1'), 164.9 (C-2'), 103.5 (C-3'), 163.0 (C-4'), 108.0 (C-5'), 132.2 (C-6'), 204.0 (C=O), $39.6(\alpha)$, 27.7 (B), 25.8 (C-1"), 121.7 (C-2"), 138.6 (C-3"), 39.6 (C-4"), 26.3 (C-5"), 123.7 (C-6"), 132.1 (C-7"), 25.7 (C-8"), 17.7 (C-9"), 16.2 C-10") [19].

AC-33 (8-geranyl-4',5,7-trihydroxyflavone), white crystal, ${ }^{1} \mathrm{H}-\mathrm{NMR}$ (in $\mathrm{CD}_{3} \mathrm{OD}$, ppm) $\delta_{\mathrm{H}} 5.3(1 \mathrm{H}, \mathrm{dd}, \mathrm{H}-2$ ); 2.70 (1H, dd $\mathrm{H}-3 \mathrm{a})$; $3.06(1 \mathrm{H}$, dd, $\mathrm{H}-3 \mathrm{~b}) ; 5.93(1 \mathrm{H}, \mathrm{s}$, $\mathrm{H}-6)$; $3.18(2 \mathrm{H}, \mathrm{dd}, \mathrm{H}-9)$; $5.14(1 \mathrm{H}, \mathrm{t}, \mathrm{H}-10) ; 1.91(2 \mathrm{H}, \mathrm{t}$, $\mathrm{H}-12) ; 2.02(2 \mathrm{H}, \mathrm{t}, \mathrm{H}-13) ; 5.04(1 \mathrm{H}, \mathrm{t}, \mathrm{H}-14) ; 1.55(3 \mathrm{H}$, 
Table 2. Enzyme $\alpha$-glucosidase inhibition activity of the isolated flavonoid compounds from $A$. altilis leaves

\begin{tabular}{cc}
\hline & $\mathrm{IC}_{50}(\mu \mathrm{M})$ \\
\hline Quercetin & 38.40 \\
AC-51 & 24.41 \\
AC-31 & 15.73 \\
AC-33 & 49.49 \\
AA-3 & 72.20 \\
\hline
\end{tabular}

Table 3. $\mathrm{Vm}$ and $\mathrm{Km}$ values of the enzymatic reactions of $\alpha$-glucosidase with and without inhibitor (AC31)

\begin{tabular}{lll}
\hline & $\mathrm{Vm}(\mathrm{mM} / \mathrm{mnt})$ & $\mathrm{Km}(\mathrm{mM})$ \\
\hline Without Inhibitor & $0.033 \pm 0.009$ & $3.246 \pm 2.242$ \\
AC-31 $1.5 \mathrm{mM}$ & $0.012 \pm 0.001$ & $4.262 \pm 0.413$ \\
$\mathrm{AC}-313 \mathrm{mM}$ & $0.009 \pm 0.002$ & $2.934 \pm 0.170$ \\
\hline
\end{tabular}

s, H-16); $1.61(3 \mathrm{H}, \mathrm{s}, \mathrm{H}-17), 1.56(3 \mathrm{H}, \mathrm{s}, \mathrm{H}-18) ; 7.31$ $\left(2 \mathrm{H}, \mathrm{d}, J=8.56 \mathrm{~Hz}, \mathrm{H}-2^{\prime} / 6^{\prime}\right) ; 6.81(2 \mathrm{H}, \mathrm{d}, J=8.56 \mathrm{~Hz}$, $\mathrm{H}-3^{\prime} / 5^{\prime}$ ). ${ }^{13} \mathrm{C}$-NMR (in $\left.\mathrm{CD}_{3} \mathrm{OD}, \mathrm{ppm}\right) \delta_{\mathrm{C}} 80.4$ (C-2), 44.1 (C-3), 198.2 (C-4), 103.4 (C-4a), 163.2 (C-5), 96.5 (C-6), 161.7 (C-7), 109.2 (C-8), 166.2 (C-8a), 22.5 (C-9), 124.1 (C-10), 135.3 (C-11), 40.9 (C-12), 27.8 (C-13), 125.6 (C-14), 132.1 (C-15), 17.9 (C-16), 25.9 (C-17), 16.3 (C-18), 131.5 (C-1'), 129.0 (C2'/6'), 116.3 (C-3'/5'), 159.0 (C-4'). Molecular weight [M+] 409.0832 [5].

Cyclocommunol, yellow amorphous powder, ${ }^{1} \mathrm{H}-\mathrm{NMR}$ (in $\mathrm{CD}_{3} \mathrm{OD}, \mathrm{ppm}$ ) $\delta_{\mathrm{H}} 1.69(3 \mathrm{H}, \mathrm{d}, J=1.2 \mathrm{~Hz}$ $\mathrm{H}-14) ; 1.95(3 \mathrm{H}, \mathrm{d}, J=1.4 \mathrm{~Hz}, \mathrm{H}-15) ; 5.47(1 \mathrm{H}, \mathrm{d}$, $J=9.5 \mathrm{~Hz}, \mathrm{H}-12) ; 6.20(1 \mathrm{H}, \mathrm{d}, J=9.5 \mathrm{~Hz}, \mathrm{H}-11) ; 6.43$ $\left(1 \mathrm{H}, \mathrm{d}, J=2.0 \mathrm{~Hz}, \mathrm{H}-3^{\prime}\right) ; 6.63(1 \mathrm{H}, \mathrm{dd}, J=2.0,8.5 \mathrm{~Hz}$, $\left.\mathrm{H}^{\prime} 5^{\prime}\right) ; 7.70\left(1 \mathrm{H}, \mathrm{d}, J=8.4 \mathrm{~Hz}, \mathrm{H}-6^{\prime}\right) ; 6.26(1 \mathrm{H}, \mathrm{d}$, $J=1.8 \mathrm{~Hz}, \mathrm{H}-6) ; 6.52(1 \mathrm{H}, \mathrm{d}, J=1.8 \mathrm{~Hz}, \mathrm{H}-8) ; 12.88(1 \mathrm{H}$, s). ${ }^{13} \mathrm{C}-N M R$ (in $\left.\mathrm{CD}_{3} \mathrm{OD}, \mathrm{ppm}\right) \delta_{\mathrm{C}} 160.5$ (C-2), 109.4 (C-3), 180.7 (C-4), 159.5 (C-5), 100.7 (C-6), 166.2 (C-7), 95.7 (C-8), 164.8 (C-9), 106.4 (C-10), 71.0 (C-11), 123.3 (C-12), 132.8 (C-13), 18.8 (C-14), 26.1 (C-15), 110.9 (C-1'), 140.0 (C-2'), 105.8 (C-3'), 165.5 (C-4'), 111.8 (C-5'), 127.4 (C-6'). Molecular weight [M] 352.0949 [18].

AC-31, AC-51, AC-33, and cyclocommunol were flavonoid compounds isolated previously from $A$. altilis leaves [5,17-19]. AC-31 showed the lowest $I C_{50}$ compared to quercetin, AC-51, AC-33 and cyclocommunol with $\mathrm{IC}_{50}$ value 15.73 . Its means that AC-31 has the strongest activity against enzyme $\alpha-$ glucosidase, followed by AC- 51 which also has a better $\mathrm{IC}_{50}$ value compared with quercetin as a positive control (Table 2).

From the chemical structures of the isolated flavonoid compounds, correlated with a-glucosidase inhibition activity, alleged that a hydroxyl functional group in a particular place plays important role in inhibiting the enzyme.

Kinetics study of the enzyme a-glucosidase inhibition by AC-31 compound based of Linewaver-Burk

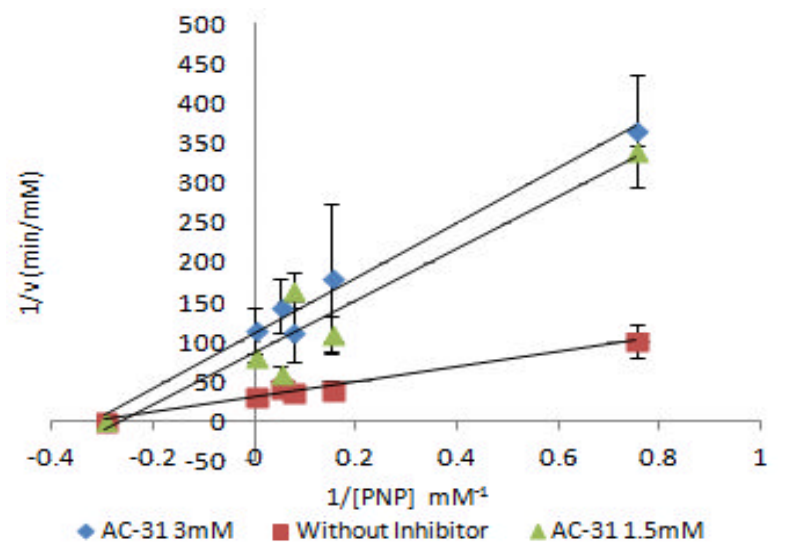

Fig 2. Kinetics inhibition of enzyme $\alpha$-glucosidase by AC-31 compound

methods showed that the Michaelis constant $(\mathrm{Km})$ value of the reaction without and with inhibitor (AC31) at a concentration of $1.5 \mathrm{mM}$ or $3 \mathrm{mM}$ was not significantly different (Fig. 2 and Table 3). The results indicated that the type of enzyme a-glucosidase resistance by compound $\mathrm{AC}-31$ is a non-competitive where the affinity of the enzyme to the substrate does not change despite the compound AC-31, it also showed that compound AC-31 occupy a different locus of the $p$-NPG substrate in the enzyme $\alpha$-glucosidase, and $\mathrm{AC}-31$ compound only affects to the reaction rate (Table 3).

\section{CONCLUSION}

Enzyme a-glucosidase inhibition assay of Artocarpus altilis leaf extract shown that ethanol extract, ethyl acetate fraction and two flavonoid compounds (AC-31 and AC-51) have antidiabetic activity stronger than quercetin as positive control with $\mathrm{IC}_{50}$ value $6.79 \mu \mathrm{g} / \mathrm{mL}, 5.98 \mu \mathrm{g} / \mathrm{mL}, 15.73 \mu \mathrm{M}$, and $24.41 \mu \mathrm{M}$, respectively. From the kinetic inhibition of enzyme a-glucosidase mechanism can be concluded that the type of inhibition of AC-31 compound is a noncompetitive.

\section{ACKNOWLEDGEMENT}

We are grateful to Indonesian Institute of Sciences for supported our research by Thematic Program Research Grant.

\section{REFERENCES}

1. Kasahara, S., and Hemmi, S., 1986, Medicinal Herb Index in Indonesia. P.T. Eisai Indonesia, Bogor, pp. 184. 
2. Wang, Y., Kedi, X., Lin, L., Pan, Y., and Zheng, X., 2007, Phytochemistry, 68 (9), 1300-1306.

3. Nagappa, N.A., Thakurdesai, P.A., Venkat, R.N., and Singh, J., 2003, J. Ethnopharmacol., 88 (1), 4550.

4. Oh, W.K., Lee, C.H., Lee, M.S., Bae, E.Y., Sohn, C.B., Oh, H., Kim, B.Y., and Ahn, J.S., 2005, J. Ethnopharmacol., 96 (3), 411-415.

5. Lotulung, P.D.N., Fajriah, S., Sundowo, A., and Filaila, E., 2009, Indo. J. Chem., 9 (3), 466-469.

6. Gao, H., Nishioka, T., Kawabata, J., and Kasai, T., 2004, Biosci. Biotechnol. Biochem., 68 (2), 369-357.

7. Dewi, R.T., Iskandar, Y., Hanafi, M., Kardono, L.B.S., Angelina, M., Dewijanti, D.I., and Banjarnahor, S.D.S., 2007, Pak. J. Biol. Sci., 10 (18), 3131-3135.

8. Meng, P., and Zhou, X., 2012, Med. Chem. Res., 21 (12), 4422-4429.

9. Annapurna, A., Kumar, V.K., Rao, N.K., Harish, G., and Kumar, K.V., 2001, Indian J. Pharm. Sci., 63, 273-278.

10. Rao, N.K., 2006. BMC Complement. Altern. Med., 6 (17), 1-6.
11. Iwai, K., 2008, Plant Foods Hum. Nutr., 63 (4), 163-169.

12. Peyrieras, N., Bause, E., Legler, G., Vasilov, R., Claesson, L., Peterson, P., and Ploegh, H., 1983, EMBO J., 2 (6), 823-832.

13. Göke, B., and Herrmann-Rinke, C., 1998, Diebetes Metab. Rev., 14 (S1), S31-S38.

14. Kim, Y-M., Wang, M-H., and Rhee, H-I., 2004, Carbohydr. Res., 339 (3), 715-717.

15. Jones, A.M.P., Ragone, D., Tavana, N.G., Bernotas, D.W., and Murch, S.J., 2011, Ethnobotany Res. Appl., 9, 129-149.

16. Lotulung, P.D.N., 2007, Artocarpus Communis Leaves as Antidiabetic Phytopharmaca, Progress Report LIPI Competitive Project.

17. Lotulung, P.D.N., Fajriah, S., Hanafi, M., and Filaila, E., 2008, Pak. J. Biol. Sci., 11 (2), 25172520.

18. Lin, C-N., and Shieh, W-L., 1992, Phytochemistry, 31 (8), 2922-2924.

19. Syah, Y.M., Achmad, S.A., Bakhtiar, E., Hakim, E.H., Juliawaty, L.D., and Latip, J., 2006, Jurnal Matematika dan Sains, 11 (3), 100-104. 